\title{
Game Edukasi Adventure Pengenalan Komponen Komputer Untuk Peserta Didik SMK Dar El Hikmah Pekanbaru
}

\author{
Dede Dermawan, Rahamad Al Rian, Pratama Benny Herlandy \\ program Studi Pendidikan Teknik Informatika FKIP Universitas Muhammadiyah Riau \\ e-mail: 150601031@ student.umri.ac.id
}

\begin{abstract}
Abstrak
Media pembelajaran yang hanya menggunakan buku ajar, sesekali menggunakan power point dan pendidik menjelaskan materi dengan metode konvensional yang dilakukan terus menerus tanpa adanya variasi akan menyebabkan kejenuhan. Oleh karena itu, penelitian ini bertujuan untuk membuat game edukasi adventure pengenalan komponen komputer. Untuk mencapai tujuan diatas digunakan penelitian pendidikan dengan jenis penelitian Research and Develompment $(R \& D)$. Pengembangan media pembelajaran mengacu pada model Multimedia Instructional Design Process. Adapun tahapan Multimedia Instructional Design Process yaitu, Analysis, Design, Deveploment, Implementation, Evaluations. Data yang dikumpulkan melalui angket (skala likert) pada saat uji coba. Hasil penilaian dari ahli materi terhadap kelayakan game edukasi adventure mencapai skor rerata 4,58 dengan kategori sangat baik. Hasil penilaian dari ahli media terhadap kelayakan game edukasi adventure mencapai skor rerata 4,33 kategori sangat baik. Hasil penilaian dari peserta didik terhadap game edukasi adventure pada uji coba mencapai skor rerata 4,56 dengan kategori sangat baik. Berdasarakan hasil penelitian yang dilakukan diperoleh kesimpulan bahwa game edukasi adventure ini layak digunakan sebagai media pembelajaran.
\end{abstract}

Kata kunci : game edukasi, game adventure, media pembelajaran, komponen komputer, construct 2.

\section{Abstract}

\section{Pendahuluan}

Peningkatan mutu pendidikan dapat terwujud apabila proses dalam kegiatan pembelajaran berjalan dengan lancar, terarah, serta dapat mencapai tujuan pembelajaran itu sendiri. Ada beberapa faktor yang dapat mempengaruhi proses pembelajaran antara lain pendidik, peserta didik, fasilitas, dan media yang digunakan dalam pembelajaran. Keseluruhan faktor tersebut memiliki keterkaitan satu dengan yang lainnya. Pendidik menyampaikan materi ajar menggunakan media pembelajaran untuk memudahkan peserta didik dalam memahami materi yang disampaikan, sehingga proses pembelajaran dapat terwujud secara efektif dan efisien. Media pembelajaran dapat berupa alat peraga, alat simulasi, gambar, animasi, audio, game dan media lainya.

Oemar Hamalik (1986) menyatakan bahwa media pembelajaran adalah hubungan komunikasi interaksi akan berjalan lancar dan tercapainya hasil yang maksimal, apabila menggunakan alat bantu yang disebut media komunikasi (wandah,2017:5). Perkembangan media pembelajaran dipengaruhi oleh berbagai faktor, salah satunya adalah perkembangan teknologi informasi. Seiring dengan perkembangan teknologi informasi, sebuah media pembelajaran kini mulai dikembangankan dengan memadukan dunia pendidikan dan dunia hiburan. Hal ini dilakukan karena peserta didik akan lebih tertarik untuk mempelajari dunia pendidikan jika di dalam proses pembelajaran dapat membuat mereka merasa senang untuk belajar tanpa adanya persaan terpaksa. 
Dalam upaya untuk mengikuti perkembangan zaman, game edukasi mulai dikembangkan secara modern. Pengembangan game ini dapat dilakukan dengan menggunakan perangkat elektronik seperti komputer. Peran komputer dalam pengembangan game edukasi adalah sebagai salah satu sarana membuat dan memainkan game. Komputer dipilih karena produk yang dihasilkan dapat digunakan untuk berbagai perangkat elektronik lainnya, seperti komputer, tablet, handphone, game console, dan lain sebagainya.

Hasil observasi yang dilakukan di SMK Dar El Hikmah Pekanbaru adalah saat pendidik menjelaskan materi, pendidik masih kurang menggunakan media pembelajaran yang bervariasi dalam pembelajaran, media yang digunakan yaitu buku ajar dan sesekali menggunakan Microsoft powerpoint saja dan pendidik masih menggunakan metode konvensional. Komunikasi yang terjadi hanya satu arah antara guru dan siswa. Metode konvensional dilakukan terus menerus tanpa adanya variasi akan menyebabkan kejenuhan sehingga partisipasi dan motivasi peserta didik dalam pembelajaran masih kurang. Berdasarkan peneliti amati pada peserta didik kelas X TI memiliki kecendrungan menyukai bermain game pada saat jam istirahat, oleh karena itu peneliti tertarik membuat media pembelajaran berupa game edukasi.

Pokok bahasan pengenalan komponen komputer sangat penting karena peserta didik diharapkan dapat memiliki keterampilan dalam perakitan komputer. Oleh karena itu, perlu adanya media pembelajaran/Game edukasi yang bisa menumbuhkan motivasi belajar bagi perserta didik. Salah satu cara yang dapat dilakukan yaitu dengan melakukan pengembangan media pembelajaran yang dapat menunjang proses pembelajaran. game edukasi ini sebagai sarana pengenalan komponen komputer yang dapat dijadikan alternatif untuk memberikan wawasan kepada peserta didik SMK Dar El Hikmah Pekanbaru agar mereka lebih dapat mengetahui berbagai perangkat yang ada di komputer dengan cara yang menyenangkan.

\section{Metode Penelitian}

Metode penelitian yang digunakan pada penelitian ini adalah metode penelitian Research and Development $(R \& D)$. Metode Penelitian dan Pendidikan adalah suatu rangkaian atau proses dalam rangka mengembangkan produk baru atau menyempurnakan produk yang sudah ada. Menurut Sugiyono (2010), metode Penelitian dan Pengembangan adalah metode yang digunakan untuk menghasilkan produk tertentu dan menguji keefektifan produk tersebut. Metode perancangan game yang digunakan adalah model pengembangan multimedia Menurut Lee dan Owens (2004) Multimedia Instructional Design Process yaitu Analysis, Design, Development, Implementation, and Evaluation. Produk yang dihasilkan dari pengembangan ini berupa media pembelajaran dalam bentuk perangkat lunak yang dikembangkan dengan Software Construct 2 berbasis HTML 5 dan apk.

2.1 Prosedur Pengembangan

1. Tahap Analisis

Dalam tahap analisis dilakukan pengumpulan informasi yang dibutuhkan untuk mengembangkan game edukasi adventure. Tahap analisis ini mencakup analisis kebutuhan dan analisis data.

2. Tahap Desain

Tahap desain dilakukan untuk mendesain perangkat lunak yang akan dikembangkan. Tahap ini meliputi pengumpulan objek rancangan, desain flowchart, desain storyboard.

3. Tahap Pengembangan

Pada tahap ini seluruh komponen yang telah dipersiapkan pada tahap design disatukan menjadi game edukasi adventure menggunakan software construct 2 . Tahap pengembangan ini sesuai dengan flowchart dan storyboard yang sudah dirancang atau dibuat. Komponen game edukasi adventure ini terdiri dari materi, gambar, audio, latihan/evaluasi dan lain-lain dimasukkan dengan cara Mengimport kedalam program 
dan setelah itu diberi perintah di eventsheet yang ada di construct 2 dan melakukan pengujian fungsi navigasi.

4. Implementasi

Tahap implementasi dilakukan setelah menyelesaikan Tahap sebelumnya dengan menjalankan game edukasi adventure dan melihat apakah ada kesalahan atau tidak dalam media pembelajaran tersebut. Tahap pertama pada tahap ini yaitu validasi media dan materi yang dilakukan oleh ahli media dan ahli materi. Dilakukannya validasi ini untuk mengetahui kelayakan game edukasi adventure yang telah dibuat. Revisi terhadap game edukasi adventure ini dilakukan sesuai saran dan komentar dari ahli media dan ahli materi. Setelah lolos validasi, dilakukan pengujian yang melibatkan pengguna akhir sebagai responden dalam hal ini yaitu peserta didik kelas X TI di SMK Dar El Hikmah Pekanbaru .

5. Tahap Evaluasi

Tahap evaluasi yaitu memperbandingkan hasil yang didapatkan pada tahap uji coba. selain memperbandingkan hasil yang di peroleh dari ahli media dan materi,peneliti juga menganalisis data yang diperoleh dari responden yaitu peserta didik. Semua tahapan evaluasi ini bertujuan untuk kelayakan produk akhir. Layak dari segi isi, desain dan user friendly.

\subsection{Desain Uji Coba Produk}

Bagian yang sangat penting dalam penelitian dan pengembangan (R\&D) adalah uji coba produk, karena bertujuan untuk mengetahui apakah produk yang telah dibuat layak digunakan atau tidak dalam mencapai sasaran dan tujuan serta kesesuaian dengan pengguna untuk menyelesaikan masalah pembelajaran. Uji coba ini dilakukan dua kali : (1) revisi oleh ahli materi dan ahli media (2) Uji pengguna yaitu peserta didik.

game ini divalidasi oleh ahli materi dan ahli media. Setelah divalidasi oleh ahli materi dan ahli media, media kemudian direvisi sehingga diperoleh game yang telah revisi .game yang telah revisi kemudian diuji cobakan oleh peserta didik yang akan menghasilkan produk akhir game edukasi adventure pengenalan komponen komputer untuk peserta didik kelas X TI Di SMK Dar El Hikmah Pekanbaru.

\subsection{Subjek Uji Coba}

Penelitian ini melibatkan peserta didik kelas X TI SMK DAR EL HIKMAH Pekanbaru sebagai responden. Ahli media dan ahli materi untuk validasi game edukasi adventure

\subsection{Teknik dan Instrumen Pengumpulan Data}

Pengumpulan data merupakan langkah awal dalam melakukan penelitian yang akan kita teliti. Data yang dikumpulkan berasal dari dari ahli media sebagai validator media, ahli materi sebagai validator materi dan peserta didik sebagai responden untuk menilai game edukasi ini. Teknik pengumpulan data yang digunakan dalam penelitian ini adalah dengan menggunakan observasi dan wawancara terlebih dahulu untuk menganalisis dan mengetahui kebutuhan media pembelajaran pokok bahasan pengenalan komponen komputer kelas X SMK Dar El Hikma Pekanbaru. Selanjutnya untuk pengambilan data menggunakan angket.

\subsection{Teknik Analisis Data}

Data yang diperoleh melalui angket dari ahli media, ahli materi dan peserta didik yang berupa nilai kualitatif yang dikonversikan menjadi nilai kuantitatif. Data hasil penilaian oleh ahli media dan ahli materi dianalisis menggunakan langkah-langkah sebagai berikut :

$$
\bar{x}=\sum_{i}^{n}=1 x_{i}
$$

Keterangan :

$$
\bar{x} \quad=\text { rata-rata skor yang diperoleh }
$$




$$
\begin{array}{ll}
\sum_{i}^{n}=1 x_{i} & =\text { jumlah skor yang diperoleh ke-i } \\
n & =\text { banyaknya butir pertanyaan }
\end{array}
$$

Tabel 1. Kriteria Kevalidan dan Kepraktisan Media Pembelajaran

\begin{tabular}{llll}
\hline No & Rentang Skor & Rentang Skor & Kategori \\
\hline $\mathbf{1}$ & $\mathrm{Mi}+1,80 \mathrm{Sbi}<\mathrm{X}$ & $4,206<\mathrm{X}$ & Sangat Baik \\
$\mathbf{2}$ & $\mathrm{Mi}+0,60 \mathrm{Sbi}<\mathrm{X} \leq \mathrm{Mi}+1.80 \mathrm{Sbi}$ & $3,402<\mathrm{X} \leq 4,206$ & Baik \\
$\mathbf{3}$ & $\mathrm{Mi}-0,6 \mathrm{Sbi}<\mathrm{X} \leq \mathrm{Mi}+0,60 \mathrm{Sbi}$ & $2,598<\mathrm{X} \leq 3,402$ & Cukup Baik \\
$\mathbf{4}$ & $\mathrm{Mi}-0,80 \mathrm{Sbi}<\mathrm{X} \leq \mathrm{Mi}+0.6 \mathrm{Sbi}$ & $1,794<\mathrm{X} \leq 2,598$ & Kurang Baik \\
$\mathbf{5}$ & $\mathrm{X} \leq \mathrm{Mi}-1,80 \mathrm{Sbi}$ & $\mathrm{X} \leq 1,794$ & Sangat \\
& & & Kurang Baik \\
\hline
\end{tabular}

Keterangan :

Menghitung rata-rata tiap aspek dengan rumus berikut :

Rata-rata tiap aspek $=\frac{\text { jumlah skor Rata-rata tiap indikator }}{\text { jumlah indikator }} \times 100$

Untuk menghitung kualitas berdasarkan penilaian dalam bentuk presentase menggunakan rumus berikut :

$$
\text { Presentase Kualitas }(\%)=\frac{\text { skor hasil observasi }}{\text { skor yang diharapkan }} \times 100 \%
$$

\section{Hasil dan Pembahasan}

3.1 hasil pengembangan produk

Secara garis besar media pembelajaran game edukasi meliputi :

a. Tampilan halaman menu utama game edukasi

Halaman menu utama muncul ketika game edukasi dijalankan.

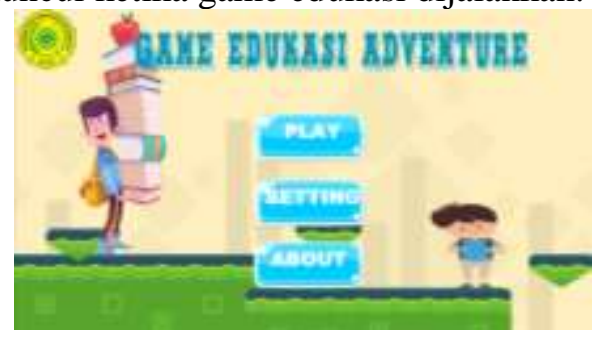

Gambar 1 Halaman Menu Utama

b. Tampila halaman select level

Halaman select level muncul ketika menekan tombol play. Halaman select level terdapat tombol level yang akan menuju ke dalam permain. Berikut tampilan select level.

c. Tampilan halaman level 1

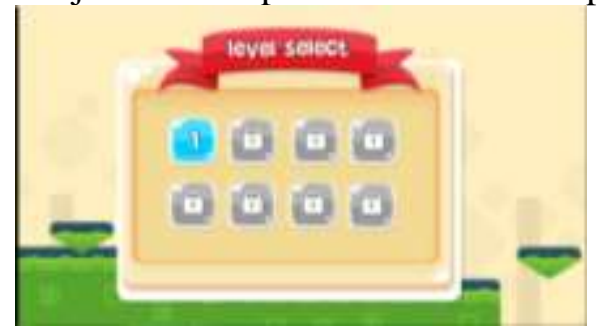

Gambar 2 Halaman Select Level 
Berikut tampilan level 1 .

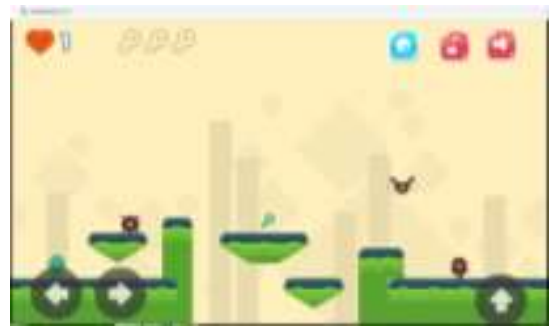

Gambar 3 Halaman Level 1

d. Tampilan pop up game over

Pop up game over muncul apabila player jatuh atau player mengenai musuh sebanyak 3 kali. Berikut tampilan game over.

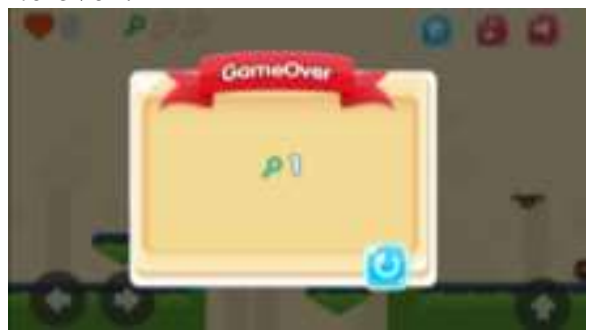

Gambar 4 Pop Up Game Over

e. Tampilan pop up materi

Pop up materi muncul apabilah player mendapatkan kunci, pada pop up materi terdapat materi komponen komputer beserta gambarnya dan terdapat tombol keluar untuk melanjutkan permainan. Berikut tampilan materi.

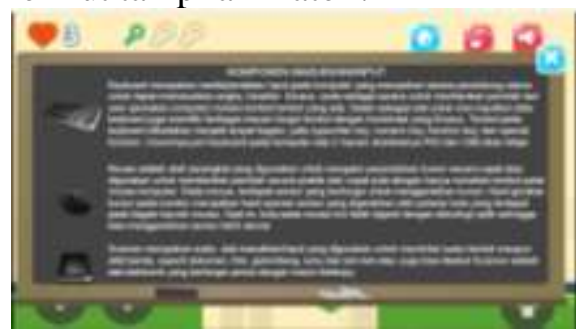

Gambar 5 Pop Up Materi

f. Tampilan halaman latihan/soal level 1

Pada halaman latihan terdapat berapa atribut yaitu text soal, jawaban a,b,c dan d, score, timer,tombol home dan tombol musik. Berikut tampilan latihan/soal

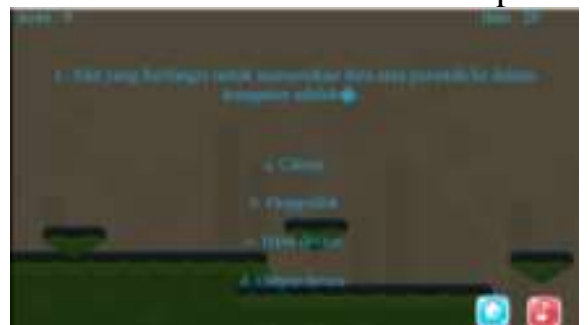

Gambar 6 Halaman Latihan/Soal Level 1

g. Tampilan pop up level complete

Berikut tampilan level complete 
h. Tampilan halaman level 2

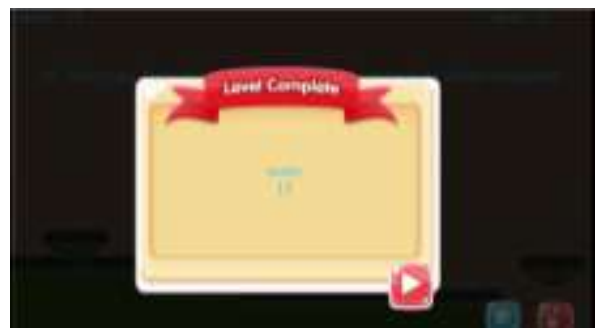

Gambar 7 Pop Up Level Complete

Berikut tampilan level 2

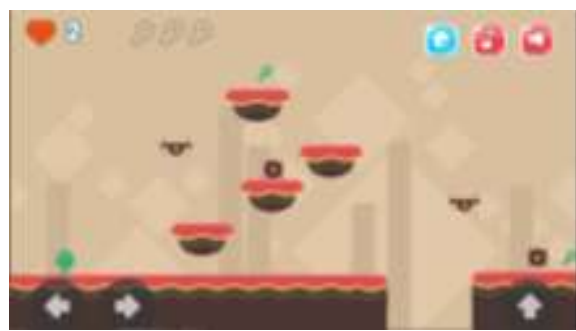

Gambar 8 Halaman Level 2

i. Tampilan halaman latihan/soal level 2

Berikut tampilan soal level 2.

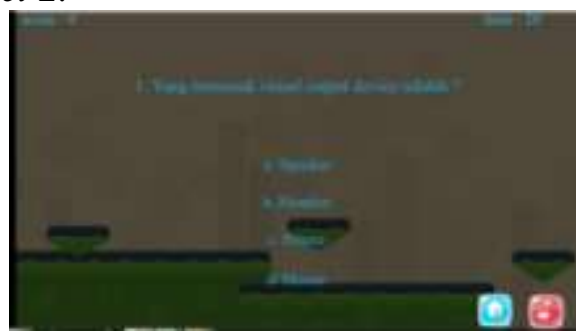

Gambar 9 Halaman Latihan/Soal Level 2

j. $\quad$ Tampilan pop up setting

Pada halaman setting terdapat tombol music dan sound untuk mengatur on/off nya dan terdapat tombol keluar. Berikut tampilan setting.

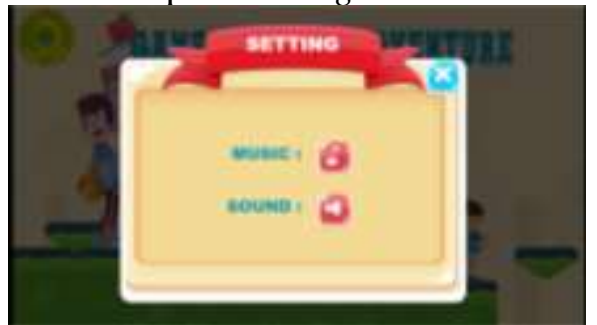

Gambar 10 Pop Up Setting

k. Tampilan pop up about

Pada halaman about terdapat infomasi mengenai identitas pembuat game dan logo fkip universitas muhammadiya riau . Berikut tampilan about.

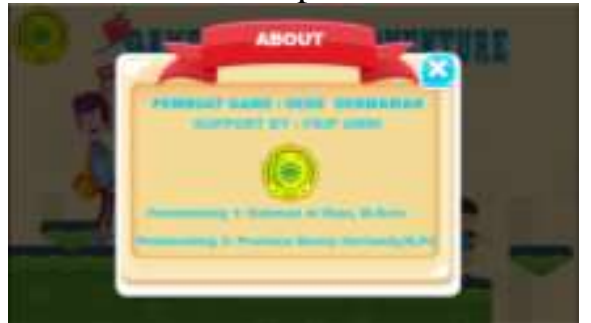

Gambar 11 Pop Up About 


\subsection{Hasil Uji Coba Produk}

Data yang dikumpulkan melalui angket (skala likert) pada saat uji coba. Hasil penilaian dari ahli materi terhadap kelayakan game edukasi adventure mencapai skor rerata 4,58 dengan kategori sangat baik. Hasil penilaian dari ahli media terhadap kelayakan game edukasi adventure mencapai skor rerata 4,33 kategori sangat baik . Hasil penilaian dari peserta didik terhadap game edukasi adventure pada uji coba mencapai skor rerata 4,58 dengan kategori sangat baik . Berdasarakan hasil penelitian yang dilakukan diperoleh kesimpulan bahwa game edukasi adventure ini layak digunakan sebagai media pembelajaran.

\subsection{Kajian Produk Akhir}

Karakteristik dari game edukasi adventure ini memiliki keunggulan. Adapun keunggulannya antara lain adalah:

1. Game edukasi ini dikemas dengan cara yang portable yaitu bisa digunakan di android dengan format apk atau di pc dengan format html5

2. Game edukasi ini mudah digunakan untuk peserta didik kelas $X$

3. Penyajian media pembelajaran bukan hanya sebatas materi saja akan tetapi terdapat game yang menarik minat peserta didik.

\subsection{Keterbatasan Pengembangan}

Dalam pengembangan game edukasi adventure ini terdapat beberapa keterbatasan dalam pengembangan, antara lain:

1. Pengembangan media ini hanya membahas pengenalan komponen komputer yang merupakan sub bab dari mata pelajaran komputer dan jaringan dasar.

2. Game edukasi ini hanya dapat mengedit materi dan soal dengan menggunakan construct2.

\section{Kesimpulan}

Berdasarkan hasil penelitian dan pembahasan tentang pengembangan game edukasi adventure dengan construct 2 telah dikembangkan maka dapat diambil kesimpulan sebagai berikut:

1. Game edukasi adventure pengenalan komponen kompter untuk kelas X TI di SMK Dar El Hikmah Pekanbaru telah dibangun dengan 5 tahapan yaitu : (1) analysis (tahap analisis), (2) desain (tahap perancangan), (3) development (tahap pengembangan), (4) implementation (tahap implementasi), (5) evaluation (tahap evaluasi). Tahap analisis, melakukan analisis mengidentifikasi mengenai kurikulum, dan silabus dan menganalisis kebutuhan apa saja yang dapat mengatasi masalah saat proses pembelajaran. Tahap perancangan, tahap ini membuat flowchart, storyboard, pengumpulan objek rancangan dan penyusunan instrumen. Tahap pengembangan, proses pembuatan game edukasi sesuai dengan flowchart dan storyboard dan pengujian navigasi. T'ahap implementasi, pada tahap ini dilakukan validasi media dan materi yang dilakukan oleh ahli media dan ahli materi.

Dilakukannya validasi ini untuk mengetahui kelayakan game edukasi adventure yang telah dibuat. Revisi terhadap game edukasi adventure ini dilakukan sesuai saran dan komentar dari ahli media dan ahli materi. Setelah lolos validasi , dilakukan pengujian yang melibatkan pengguna akhir sebagai responden dalam hal ini yaitu peserta didik kelas X TI di SMK Dar El Hikmah Pekanbaru. Pada tahap terakhir yaitu tahap evaluasi, berdasarkan hasil review para ahli dan uji coba lapangan yang sudah dilakukan pada tahap implementasi selanjutnya dilakukan dua tahap analisis data yaitu analisis data kualitatif dan kuantitatif. Maka dari tahapan-tahapan yang telah dilakukan, game edukasi ini menjadi media pembelajaran yang menarik karena dilengkapi dengan audio, game adventure, teks, dan gambar serta efisien, serta sudah tervalidasi oleh ahli 
materi dan ahli media. Selanjutnya menghasilkan media pembelajaran dalam bentuk file *.apk dan .html5 .

2. Game edukasi adventure pengenalan komponenn komputer ini teruji kelayakannya pada validasi dan uji coba kelayakan. Hasil uji kelayakan media pembelajaran berdasarkan ahli materi mendapatkan kategori sangat baik dengan rata-rata skor keseluruhan 4,58 Berdasarkan ahli media mendapatkan kategori sangat baik dengan rata-rata skor keseluruhan 4,33. Berdasarkan uji coba responden yaitu peserta didik, media pembelajaran ini mendapatkan kategori sangat baik dengan rata-rata skor keseluruhan aspek 4,56. Maka media pembelajaran ini layak digunakan untuk mendukung kegiatan belajar mengajar.

\section{Daftar Pustaka}

Arifiati Fitri Anggraini (2016).Aplikasi Game Edukasi Petualangan Nusantara

Arif S. Sadiman (2014). Media pendidikan: pengertian, pengembangan dan pemanfaatannya. Jakarta: Rajawali Press.

Astri Nur Indahsari Dkk (2018). Game Edukasi Pengenalan Komponen Komputer Berbasis Android Sebagai Pengembangan Media Pembelajaran

A. Trisnadoli, I. Muslim, and W. Novayani,(2016) "Software Quality Requirement Analysis Educational Mobile Game with Tourism Theme," J. Softw., vol. 11, no. 12, pp. 12501257 ,

Azhar, A. (2016). Media Pembelajaran. Jakarta: Rajawali Press.

Burhan Arifin Dkk (2018). Aplikasi Game Puzzle Pengenalan Perangkat Komputer Berbasis Android

Fendi Aji Purnomo (2016). Pembuatan Game Edukasi Petualangan Si Gemul Sebagai Pembelajaran Pengenalan Daerah Solo Rayapada Anak.

Fransiskus Tjiptabudi (2016). Game Edukasi Sebagai Media Pengenalan Lingkungan Dan Pembelajaran TIK Bagi Siswa Kelas I Sekolah Dasar

Putri, Alya Andriani (2018). Media Pembelajaran Interaktif Dengan Lectora Inspire Pada Pokok Bahasan Perakitan Komputer

Sugeng Santoso Dkk (2017). Pengembangan Game Edukasi Berbasis Android Untuk AnakAnak Usia Dini

Sumardiono (2012). Pengembangan Media Pembelajaran dengan Memanfaatkan Multimedia Komunikasi Interaktif: Flow Chart CAI dan Strategi Instruksional.

Wanda Wibawanto (2017). Desain Dan Pemrograman Multimedia Pembelajaran Interaktif. Jawa Timur: Cerdas Ulet Kearatif.

Widoyoko, Eko Putro (2012). Teknik Penyusunan Instrument Penelitian. Yogyakarta :

Pustaka Pelajar 